OPEN ACCESS

Edited by:

Camille Eichelberger Granada, University of Taquari Valley, Brazil

Reviewed by:

Juan M. Gonzalez,

Spanish National Research Council (CSIC), Spain

Ademir Araujo,

Federal University of Piauí, Brazi

${ }^{*}$ Correspondence:

Honghui Zhu

zhuhh@gdim.cn

Qing Yao

yaoqscau@scau.edu.cn

Specialty section

This article was submitted to

Plant Microbe Interactions,

a section of the journal

Frontiers in Microbiology

Received: 09 October 2018

Accepted: 28 March 2019

Published: 12 April 2019

Citation:

Zhou Y, Qin Y, Liu X, Feng Z Zhu H and Yao Q (2019) Soil Bacterial Function Associated With Stylo (Legume) and Bahiagrass (Grass) is

Affected More Strongly by Soil Chemical Property Than by Bacterial

Community Composition.

Front. Microbiol. 10:798.

doi: 10.3389/fmicb.2019.00798

\section{Soil Bacterial Function Associated With Stylo (Legume) and Bahiagrass (Grass) Is Affected More Strongly by Soil Chemical Property Than by Bacterial Community Composition}

\author{
Yang Zhou',2, Yongqiang Qin'1, Xiaodi Liu'1, Zengwei Feng', Honghui Zhu²* and \\ Qing $\mathrm{YaO}^{1 *}$
}

\begin{abstract}
${ }^{1}$ College of Horticulture, South China Agricultural University, Guangdong Province Key Laboratory of Microbial Signals and Disease Control, Guangdong Engineering Research Center for Litchi, Guangdong Engineering Research Center for Grass Science, Guangzhou, China, ${ }^{2}$ Guangdong Institute of Microbiology, State Key Laboratory of Applied Microbiology Southern China, Guangdong Provincial Key Laboratory of Microbial Culture Collection and Application, Guangzhou, China
\end{abstract}

Soil microbes are driver of nutrient cycling, with microbial function affected by community composition and soil chemical property. Legume and grass are ubiquitous in many ecosystems, however, their differential effects on microbial function are less understood. Here we constructed compartmented rhizobox planted with stylo (Stylosanthes guianensis, legume) or bahiagrass (Paspalum natatum, grass) to compare their influences on bacterial function and to investigate the determinant of bacterial function. Soils in root compartment and in near (0-5 mm from root compartment) or far (10-15 mm from root compartment) rhizosphere were sampled. Soil chemical properties, bacterial community composition and function were characterized. Results indicate that plant species and distance significantly affected bacterial function. The activities of beta-xylosidase, nitrate reductase and phosphomonoesterase were higher in stylo soil than in bahiagrass soil, while leucine-aminopeptidase activity and nos $Z$ abundance were vice versa. Rhizosphere effect was obvious for the activities of betaglucosidase, beta-xylosidase, chitinase, and the abundances of AOB-amoA, nirS, nosZ. Statistical analysis revealed that soil chemical property was significantly associated with bacterial function, with a higher coefficient than bacterial community composition. These data suggest that stylo and bahiagrass differentially affect bacterial function, which is affected more strongly by soil chemical property than by community composition.

Keywords: soil bacterial function, soil bacterial community composition, soil chemical property, soil enzyme activity, legume, grass

\section{INTRODUCTION}

Rhizosphere is a critical micro-niche for soil microbes consuming rhizodeposits and in turn increasing the nutrient availability to themselves and plants (Knee et al., 2001; Paterson, 2003; Adesemoye et al., 2008). Accumulating evidence reveals the importance of rhizosphere microbes in plant growth performance (Adesemoye et al., 2008; Kolton et al., 2017). Previous studies clearly 
showed that soil microbial community structure was affected by the distance from rhizoplane (Marilley et al., 1998; Kandeler et al., 2002), and plants selected rhizosphere microbial community in terms of both structure and function (Kourtev et al., 2003; Kirk et al., 2005; Pivato et al., 2017). These reports highlight the necessity to reveal the influences of different plant species on rhizosphere microbial function in relation to community structure and composition.

Root deposits, especially root exudates, are the main compounds regulating microbial communities (Haichar et al., 2008; Guo et al., 2017). Difference in nutrient requirement of plants (plant nutritional strategy) can also result in the differential regulation of microbial community (Thion et al., 2016; Guyonnet et al., 2017). Legume and grass are two important plant groups with contrasting features regarding root exudates and nutrient requirements (Rovira, 1969; Isobe and Tsuboki, 1998; Gransee and Wittenmayer, 2000). For example, legume roots exuded more amino acids and sugar than grass roots, especially under low P level (Isobe and Tsuboki, 1998), and this difference in root exudate composition was confirmed by Gransee and Wittenmayer (2000). The difference in nutrient requirement between legume and grass was observed in intercropping system, where sorghum was more competitive for $\mathrm{N}$ and $\mathrm{P}$ than soybean (Ghosh et al., 2009), and barley took up more ${ }^{15} \mathrm{~N}$ than pea in both monocropping and intercropping system (Jensen, 1996). Therefore, it is expected that legume and grass differentially selected soil microbial community. Kirk et al. (2005) indicated that microbial community in the soil grown with perennial ryegrass (grass) was much different from that in the soil grown with alfalfa (legume) with a similarity of $60.9 \%$ as revealed by denaturing gradient gel electrophoresis. Zhou et al. (2017) demonstrated that effects of stylo (legume) and bahiagrass (grass) on microbial community structure and function were much different. The similarity of bacterial community between stylo soil and bulk soil was $79.4 \%$, significantly lower than that (88.3\%) between bahiagrass soil and bulk soil.

Soil microbial function is fundamental to terrestrial ecosystem services (Grigulis et al., 2013). Soil microbial function can be quantified with several techniques, among which soil enzyme assay and quantification of microbial functional gene abundance are frequently employed (Burns et al., 2013; Cui et al., 2015). Factors determining soil microbial function are diverse. In a laboratory experiment with arable field soil, Hünninghaus et al. (2017) indicated that changes in microbial function (decomposition of organic matter) could be related to changes in microbial community composition, which was supported by other studies (Ofek-Lalzar et al., 2014; Fernandez et al., 2016; Galand et al., 2018). This is because the members of a particular microbial taxon (for example, species or genus) are often associated with one or more common functions. However, soil chemical property is also important player in regulating soil microbial function. For example, $\mathrm{pH}$ strongly influenced bacterial ureC (encoding one of three structural subunits in the urease enzyme) abundance and urea hydrolysis (Fisher et al., 2017), and soil organic $\mathrm{C}$, rather than soil $\mathrm{P}$, greatly affected the $p h o D$ community structure and alkaline phosphatase activity in Karst soils (Hu et al., 2018). It seems that nutrients and substrates for microbial growth (e.g., organic C), or other abiotic factors (e.g., $\mathrm{pH}$ ) changing the bioavailability of nutrients and substrates can regulate microbial functions. However, almost all of these studies explored only one side, either community composition or soil chemical property, and the comparison between the two sides is yet lacking. Consequently, further work is required to fill in the knowledge gap, revealing which is more important in regulating soil microbial function, community composition or soil chemical property.

Based on the aforementioned work and knowledge gap, we put forward the following hypotheses: (1) the influences of legume and grass on soil microbial community function are different, mainly due to their differential effects on soil chemical property and microbial community composition; and (2) soil chemical property is more effective than microbial community composition in affecting microbial function, because soil chemical property can affect microbial function both directly and indirectly via its influence on microbial community composition. In this study, two plant species (legume vs. grass) were grown in specially designed rhizoboxes to test these hypotheses. Soil bacterial community composition was characterized with 16S rRNA gene sequencing, and bacterial function was characterized using soil enzyme assay and bacterial functional gene abundance.

\section{MATERIALS AND METHODS}

\section{Soil and Plant Species}

Soil used in this study was collected from a vegetable field $\left(112.9045^{\circ} \mathrm{E}, 22.6720^{\circ} \mathrm{N}\right)$ in Heshan Hilly Interdisciplinary Experimental Station, Chinese Academy Science in Guangdong province, with laterite soil and a subtropical monsoon climate (Chen et al., 2012). Soil was air-dried, and then sieved through mesh of $2 \mathrm{~mm}$ pore size. The soil chemical properties were determined as following $\left(\mathrm{g} \mathrm{kg}^{-1}\right.$, average of three replicates): soil pH 6.05 (soil: $\mathrm{ddH}_{2} \mathrm{O} \quad 1: 2 \mathrm{v} / \mathrm{w}$ ), total organic C 11.3, dissolved organic $\mathrm{C} 0.026$, total $\mathrm{N} 0.84$, total $\mathrm{P} 0.91$, total $\mathrm{K} 10.10$, available N 0.066 , available P 0.184 , available K 0.094 . Total organic $\mathrm{C}$ and dissolved organic $\mathrm{C}$ were determined with titration after wet oxidation with $\mathrm{H}_{2} \mathrm{SO}_{4}$ and $\mathrm{K}_{2} \mathrm{Cr}_{2} \mathrm{O}_{7}, \mathrm{CN}$, available $\mathrm{P}$ and available $\mathrm{K}$ were analyzed with alkali-hydrolyzed reduction diffusing method, colorimetric method and flame photometric method (Carter and Gregorich, 2008). Total N, total P and total $\mathrm{K}$ were measured using the Kjeldahl method, the molybdenum blue colorimetric method and the flame photometric method (Zhou et al., 2017). Stylo (Stylosanthes guianensis, legume) and bahiagrass (Paspalum natatum, grass) were selected in the this study because they have been grown widely as forage or cover crops in the tropical and subtropical areas (Cui et al., 2015).

\section{Rhizobox Construction, Plant Growth, and Harvest}

The compartmented rhizobox $(12 \times 13.2 \times 11.6 \mathrm{~cm})$ was designed and constructed with acrylic plate comprising of one root compartment $(3 \mathrm{~cm})$ and two side compartments $(4 \mathrm{~cm})$. Root compartment was separated from side compartments with 
nylon mesh (25 $\mu \mathrm{m}$ pore size), preventing the root growth into side compartments. Each side compartment was further divided into several chambers with nylon mesh to establish the rhizosphere space with different distance from root compartment (Supplementary Figure S1). Soil was gently filled into the rhizobox so that the nylon mesh kept vertical and the soil surface in each compartment was the same in height. Totally, $1100 \mathrm{~g}$ soil was filled in each rhizobox.

Seeds of stylo and bahiagrass were purchased from market (Juemen Trading Co., Guangzhou), and germinated on filter paper after surface sterilization with $5 \% \mathrm{HClO}_{3}$ for $15 \mathrm{~min}$. After germination, 10 seedlings were transferred to root compartment and watered to the soil moisture of $18 \%$. For each plant species, 5 rhizoboxes were prepared as 5 replicates. Plants were cultivated in a growth chamber with a light period of $12 \mathrm{~h} / 12 \mathrm{~h}(200 \mu \mathrm{mol}$ $\mathrm{m}^{-2} \mathrm{~s}^{-1}$ ) and a day/night temperature of $28^{\circ} \mathrm{C} / 24^{\circ} \mathrm{C}$, which was suitable for plant growth according to pilot trial. All rhizoboxes were watered every day to keep the soil moisture at $18 \%$ with weighing method. Harvest was performed after 3 months of plant growth. Shoots were cut and surface soil was discarded. All roots were taken out from soil, and any root debris was carefully picked out with forceps. To investigate the spatial variation of bacterial function, the soil in the root compartment, the near (0-5 mm from root compartment) and the far (10$15 \mathrm{~mm}$ from root compartment) rhizosphere were sampled (Supplementary Figure S1).

Soil samples were homogenized, sieved through a $2 \mathrm{~mm}$ mesh, and then divided into four aliquots. One aliquot (approximately $40 \mathrm{~g}$ ) was air-dried for soil chemical property analysis, the second aliquot (approximately $20 \mathrm{~g}$ ) was stored at $4^{\circ} \mathrm{C}$ for soil enzyme assay within 1 week, and the third aliquot (approximately $20 \mathrm{~g}$ ) was stored at $-80^{\circ} \mathrm{C}$ for the extraction of soil total DNA.

\section{Analysis of Soil Chemical Property}

Soil chemical properties were determined according to a laboratory manual by Carter and Gregorich (2008). Soil moisture was determined by oven drying method. Total organic C and dissolved organic $\mathrm{C}$ were analyzed by titration after wet oxidation with $\mathrm{H}_{2} \mathrm{SO}_{4}$ and $\mathrm{K}_{2} \mathrm{Cr}_{2} \mathrm{O}_{7}$. Available $\mathrm{N}$, available $\mathrm{P}$ and available $\mathrm{K}$ were quantified by alkali-hydrolyzed reduction diffusing method, colorimetric method and flame photometric method. Nitrate and ammonium were extracted with $2 \mathrm{M}$ calcium chloride, and then determined with UV spectrophotometry and Nessler's reagent colorimetry, respectively.

\section{Soil Enzyme Assay}

To quantify soil microbial function, soil enzymes involved in the nutrient cycling were assayed, including urease, nitrate reductase, cellulase, alpha-glucosidase, cellobiosidase, betaxylosidase, beta-glucosidase, chitinase, phosphomonoesterase, and leucine-aminopeptidase.

The activities of urease, nitrate reductase and cellulase were measured with spectrophotometric method. Urease assay was performed according to Tabatabai and Bremner (1972). Briefly, $0.25 \mathrm{~g}$ soil was slightly shaken in $125 \mu \mathrm{l}$ of toluene for $15 \mathrm{~min}$, and then urea dissolved in tris buffer $\left(0.05 \mathrm{~mol} \mathrm{l}^{-1}, \mathrm{pH} 9.0\right)$ with a concentration of $0.2 \mathrm{~mol}^{-1}$ was added as substrate.
The suspension was swirled for a few seconds and incubated at $37^{\circ} \mathrm{C}$. After $24 \mathrm{~h}$ incubation, soil suspension was used to measure ammonium content by indophenols blue method on a microplate reader at $578 \mathrm{~nm}$ (Infinite M200, Tecan Co.). Nitrate reductase activity was determined by measuring the released nitrite incubating with diazo-coupling reagents ( $1 \%$ sulfanilamide in 3 $\mathrm{N} \mathrm{HCl}$ and $0.01 \% \mathrm{~N}$-(1-napthyl) ethylenediamine hydrochloride) (Lowe and Evans, 1964). Sodium nitrate $\left(40 \mu \mathrm{mol} \mathrm{l}^{-1}\right)$ dissolved in potassium succinate $\left(40 \mu \mathrm{mol} 1^{-1}, \mathrm{pH} 6.8\right)$ was added to $0.1 \mathrm{~g}$ soil with a final volume of $0.6 \mathrm{ml}$. The reaction mixture was incubated for $1 \mathrm{~h}$ at $37^{\circ} \mathrm{C}$, and stopped by $0.5 \mathrm{ml}$ diazocoupling reagents, coloration for $20 \mathrm{~min}$, and was measured spectrophotometrically at $540 \mathrm{~nm}$. Cellulase was assayed by measuring reducing power of resulting sugars with the aid of dinitrosalicylic acid (Miller et al., 1960). $0.25 \mathrm{~g}$ soil was added with Na-acetate buffer (50 mmol $\mathrm{l}^{-1}, \mathrm{pH} 6.0$ ) containing $2 \%$ carboxymethylcellulose and $125 \mu \mathrm{l}$ toluene, and then incubated for $1 \mathrm{~h}$ at $40^{\circ} \mathrm{C}$. Then the mixture was heated in boiling water bath for $15 \mathrm{~min}$. Reducing sugar in saccharification liquid was quantified with dinitrosalicylic acid method on a microplate reader at $550 \mathrm{~nm}$.

Microplate fluorometric method was used to measure the activities of the remaining soil enzymes using fluorogenic substrates according to ISO/TS 22939 (2010). Briefly, soil suspensions containing $1 \mathrm{~g}$ fresh soil in $50 \mathrm{ml}$ sodium acetate buffer $\left(0.5 \mathrm{~mol} \mathrm{l}^{-1}, \mathrm{pH} 5.5\right)$ were ultrasonically disaggregated and homogenized for $2 \mathrm{~min}$ with the output energy of $50 \mathrm{~J}$ $s^{-1}$. One hundred and sixty microliter aliquots of each soil suspension were dispensed into 96-well black microplates (Jet Bio-Filtration Co.). Forty microliter 1 of substrate solution were added to each sample well with a final concentration of $500 \mu \mathrm{mol} \mathrm{l}^{-1}$ for alpha-glucosidase, cellobiosidase, betaxylosidase and leucine-aminopeptidase, $550 \mu \mathrm{mol} \mathrm{l}^{-1}$ for betaglucosidase and phosphomonoesterase, and $200 \mu \mathrm{mol} \mathrm{l}^{-1}$ for chitinase (Supplementary Table S1). Negative control (40 $\mu \mathrm{l}$ substrate solution and $160 \mu \mathrm{l}$ sodium acetate buffer) and quench control (40 $\mu \mathrm{l}$ of $10 \mu \mathrm{mol} \mathrm{1^{-1 }}$ 4-methylumbelliferone or 7 amino-4-methylcoumarin and $160 \mu \mathrm{l}$ soil suspension) were also applied. Stock solution $\left(500 \mu \mathrm{mol} \mathrm{l^{-1 }}\right)$ was used to obtain final concentration of $0,1,5,10,25,50,100,200 \mu \mathrm{mol} 1^{-1}$ for 4-methylumbelliferone, and $0,0.1,0.5,1,5,10,25,50 \mu \mathrm{M}$ for 7-amino-4-methylcoumarin to generate standard curves. Plates were incubated for $3 \mathrm{~h}$ at $30^{\circ} \mathrm{C}$ shaking continuously. Fluorescence was measured using a microplate fluorometer (FLx800, BioTek) at $355 \mathrm{~nm}$ excitation and $460 \mathrm{~nm}$ emission.

\section{Soil DNA Extraction, MiSeq Sequencing, and Bioinformatic Analysis}

Soil total DNA was extracted from $0.25 \mathrm{~g}$ soil using PowerSoil DNA Isolation Kit (Mobio Laboratories, Carlsbad, CA, United States) according to manufacturer's protocol. DNA concentration and quality were monitored by NanoDrop 1000 spectrophotometer (Thermo Fisher Scientific, Waltham, MA, United States) and agarose gel electrophoresis.

Primer sets (Supplementary Table S2) with indexed adapters and barcode were used to amplify bacterial 16S rRNA V3-V4 
genes ( $\mathrm{Fu}$ et al., 2015). The amplicons were generated using the MetaVx ${ }^{\mathrm{TM}}$ Library Preparation kit (GENEWIZ, Inc., South Plainfield, NJ, United States). PCR reactions were carried out in $25 \mu \mathrm{l}$ with FastPfu DNA polymerase, and the amount of template DNA was $20 \mathrm{ng}$. Thermal cycling consisted of initial denaturation at $95^{\circ} \mathrm{C}$ for $3 \mathrm{~min}$, followed by 24 cycles of denaturation at $94^{\circ} \mathrm{C}$ for $30 \mathrm{~s}$, annealing at $57^{\circ} \mathrm{C}$ for $90 \mathrm{~s}$, and elongation at $72^{\circ} \mathrm{C}$ for $60 \mathrm{~s}$, finally $72^{\circ} \mathrm{C}$ for $5 \mathrm{~min}$. DNA libraries were validated by Agilent 2100 Bioanalyzer (Agilent Technologies, Palo Alto, CA, United States), and quantified by Qubit 2.0 Fluorometer (Applied Biosystems, Carlsbad, CA, United States). Then the libraries were multiplexed and loaded on an Illumina MiSeq instrument according to manufacturer's instructions (Illumina, San Diego, CA, United States). Sequencing was performed using a 300 bp paired-end (PE) configuration; image analysis and base calling were conducted with the MiSeq Control Software (MCS) embedded in the MiSeq instrument. The DNA sequences in this study have been deposited in NCBI Sequence Read Archive (SRA) with accession number SRP132275.

Raw sequence reads were de-multiplexed, quality-filtered, processed and analyzed using QIIME (Caporaso et al., 2012). Quality filtering on joined sequences was performed and sequence which did not fulfill the following criteria were discarded: sequence length $<200 \mathrm{bp}$, no ambiguous bases, mean quality score $\geq 20$. Then the sequences were compared with the reference database (RDP Gold database) using UCHIME algorithm to detect chimeric sequence, and then the chimeric sequences and singletons were removed. Sequences were grouped into operational taxonomic units (OTUs) using the clustering program VSEARCH (1.9.6) against the Silva database preclustered at $97 \%$ sequence identity (Rognes et al., 2016). The representative sequence for each OTU was picked and used the RDP classifier to annotate taxonomic information. Samples were rarified to 34642 prior to downstream analyses.

To better understand the specific influence of plant species or distance from root compartment on bacterial community composition, we designated some OTUs as biomarkers of plant species or distance as described previously (Zhou et al., 2017). Biomarkers of each plant species referred to those OTUs with significantly higher abundance in one species than in the other species, and biomarkers of each distance referred to those OTUs with significantly higher abundance in one distance than in the other two distances.

\section{Quantification of Bacterial Functional Gene Abundance}

Abundances of functional genes involved in nutrient cycling (Supplementary Table S1) were quantified using real-time quantitative PCR (RT-qPCR), including AOA-amoA, AOBamoA (encoding ammonia monooxygenase of archaea and bacteria), narG (encoding nitrate reductase), nirS (encoding nitrite reductase), nos $Z$ (encoding nitrous oxide reductase), nifH (encoding nitrogenase), alp (encoding phosphatase). The quantification of nirK was not conducted because their abundances were very low according to our pilot quantification after plant growth. The qPCR assay was conducted on a CFX96 Optical Real-Time Detection System (Bio-Rad Laboratories Inc.,

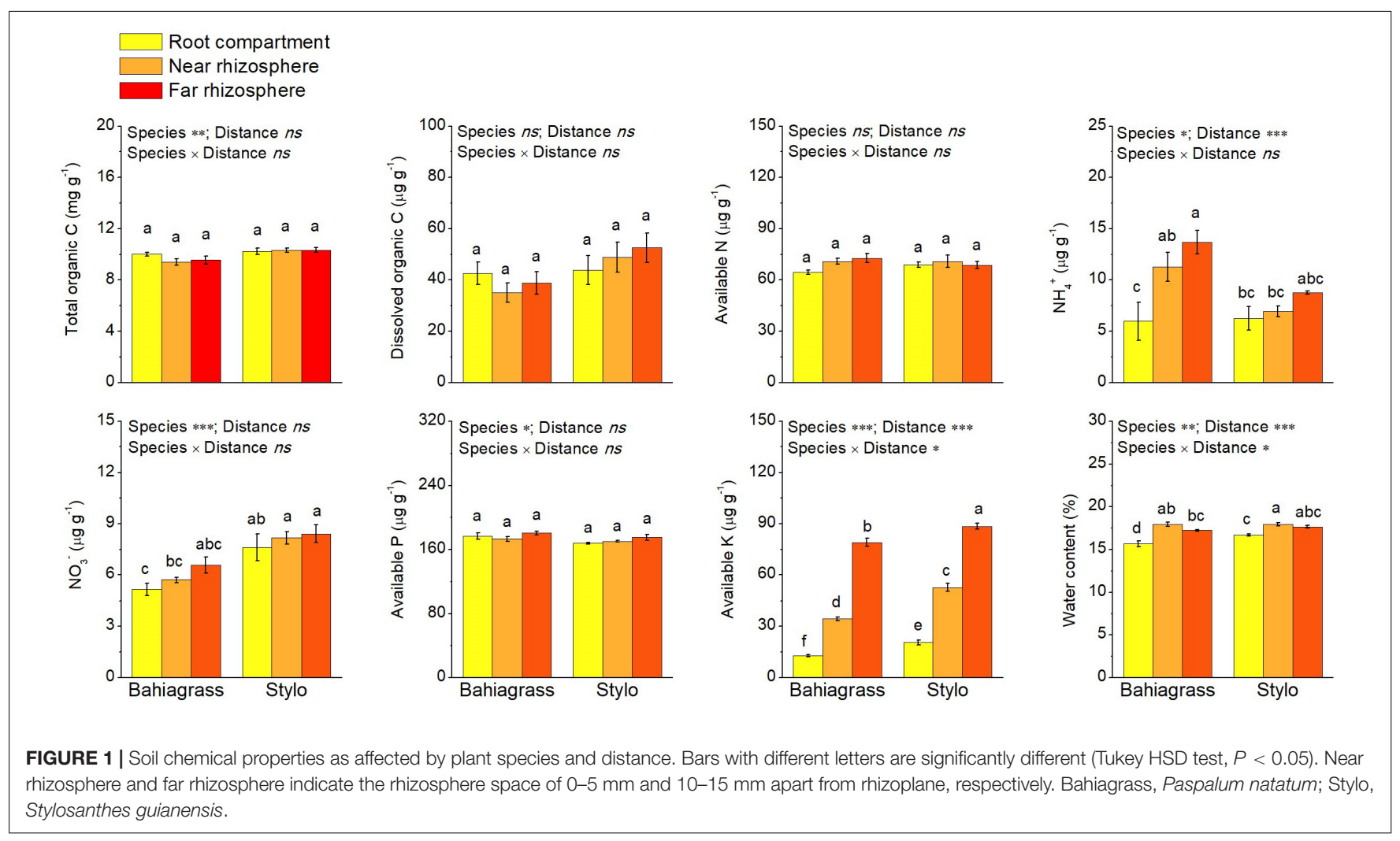


TABLE 1 | Soil bacterial community structure as affected by plant species and distance.

\begin{tabular}{|c|c|c|c|c|}
\hline Plant species & Distance & Chao1 & Simpson & Coverage \\
\hline \multirow[t]{3}{*}{ Bahiagrass } & $\mathrm{RC}$ & $1543.75 \pm 19.86^{a}$ & $0.975 \pm 0.006^{b}$ & $0.994 \pm 0.000^{a}$ \\
\hline & $\mathrm{Rn}$ & $1580.87 \pm 29.73^{a}$ & $0.986 \pm 0.003^{a b}$ & $0.995 \pm 0.000^{a}$ \\
\hline & $\mathrm{Rf}$ & $1539.75 \pm 5.64^{a}$ & $0.990 \pm 0.001^{a}$ & $0.995 \pm 0.000^{a}$ \\
\hline \multirow[t]{3}{*}{ Stylo } & $\mathrm{RC}$ & $1548.42 \pm 12.14^{\mathrm{a}}$ & $0.990 \pm 0.000^{a}$ & $0.995 \pm 0.000^{a}$ \\
\hline & $\mathrm{Rn}$ & $1545.01 \pm 5.45^{\mathrm{a}}$ & $0.992 \pm 0.000^{a}$ & $0.995 \pm 0.000^{a}$ \\
\hline & $\mathrm{Rf}$ & $1535.65 \pm 15.17^{\mathrm{a}}$ & $0.992 \pm 0.000^{a}$ & $0.995 \pm 0.000^{a}$ \\
\hline \multicolumn{5}{|c|}{ TWO-WAY ANOVA (P-VALUE) } \\
\hline \multicolumn{2}{|l|}{ Plant species (S) } & 0.41 & $<0.01$ & 0.06 \\
\hline \multicolumn{2}{|l|}{ Distance (D) } & 0.35 & 0.02 & 0.26 \\
\hline \multicolumn{2}{|l|}{$S \times D$} & 0.47 & 0.07 & 0.26 \\
\hline
\end{tabular}

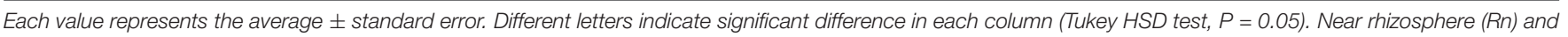

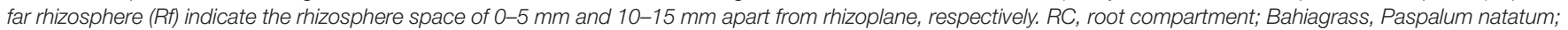
Stylo, Stylosanthes guianensis.

Hercules, CA, United States). The PCR primers and annealing temperatures are described in Supplementary Table S2. The reaction mixture contained $10 \mu \mathrm{l} 2 \times \mathrm{PCR}$ buffer $\left(\mathrm{iQ}^{\mathrm{TM}}\right.$ SYBR $^{\circledR}$ Green Supermix, Bio-Rad), $2.5 \mu$ l of each primer $(2 \mu \mathrm{mol}$ $\left.1^{-1}\right), 1 \mu$ l of template DNA and then was added with sterile deionized water to $20 \mu \mathrm{l}$. The $\mathrm{qPCR}$ conditions were as follows: an initial denaturation at $95^{\circ} \mathrm{C}$ for $5 \mathrm{~min}$; 40 cycles of denaturation at $95^{\circ} \mathrm{C}$ for $15 \mathrm{~s}$, annealing at suitable temperature (Supplementary Table S2) for $30 \mathrm{~s}$; melting curve analysis to confirm the specificity of amplification products. We normalized functional gene abundance with DNA yield of each sample, and the abundance was expressed as copy numbers per ng DNA. RTqPCR was performed with three technical replicates and negative control for the extraction was included. Amplification efficiencies of $83-91 \%$ for functional genes were obtained. Agarose gel electrophoresis was performed to check the specificity of the amplification products.

\section{Data Analysis and Statistics}

The differences in soil chemical properties and soil microbial functions (enzyme activity, functional gene abundance) among samples were estimated in $\mathrm{R}$ statistical software (version 3.1.0; R Development Core Team, 2012). Data normality and homoschedasticity were tested using Shapiro Wilk and Levene's test, respectively, at $P<0.05$. Data were log transformed if the variable did not meet the assumptions of parametric statistical tests. Pairwise comparisons between treatments were performed using Tukey's HSD post hoc tests. The effect of the two fixed factors (plant species and distance) and their interaction on soil bacterial alpha diversity were also estimated in R. Beta diversity was calculated using weighted UniFrac distance and principal coordinate analysis (PCoA) performed. Permutational multivariate of variance (PERMANOVA) was further performed in PAST to access soil bacterial community structure based on soil bacterial community profiles (Hammer et al., 2001). Mantel test (999 permutations, Spearman's rank correlation) was conducted in $\mathrm{R}$ to test the determinant of bacterial function.

To explore the direct and indirect relationships between soil chemical property, bacterial community composition and

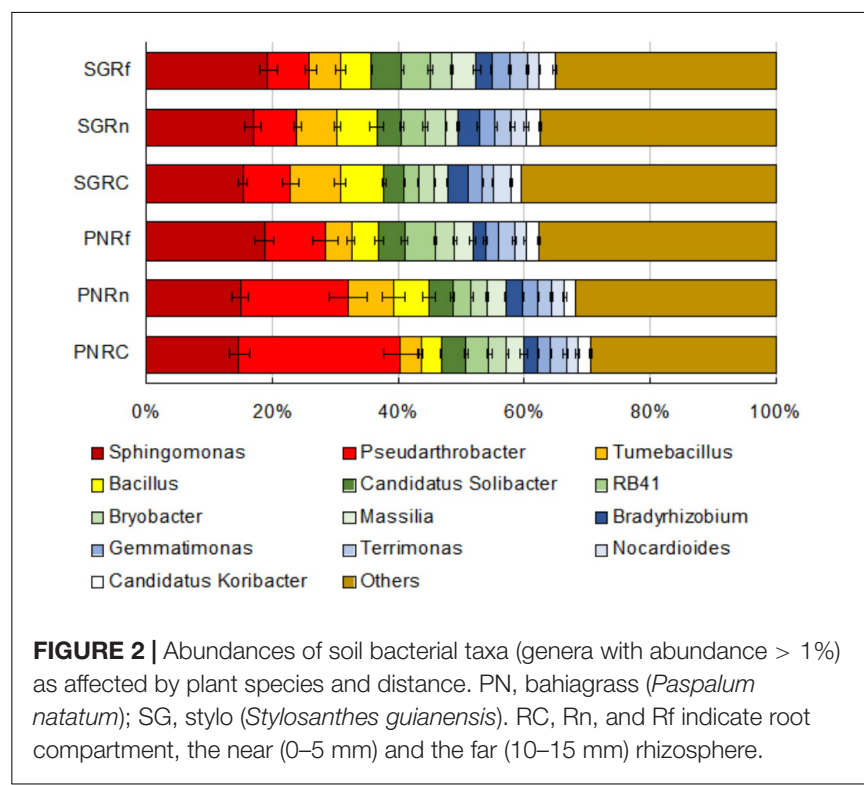

function, Partial Least Squares Path Modeling (PLS-PM) in the R “plspm” packages were used (Barberán et al., 2014). For PLS-PM, the measured soil chemical properties were used to perform Mantel test with Bray-Curtis dissimilarity of microbial function in the package "vegan." Variables significantly related were retained for path analysis. PCoA was again performed to simplify the variance of community composition (Comp. 1 and Comp. 2) and function (Funct. 1 and Funct. 2), then the first and second coordinate were used to proxy the variance of microbial function across different samples (Wei et al., 2013).

\section{RESULTS}

\section{Soil Chemical Property as Affected by Plant Species and Distance}

We found that plant species and/or distance affected most of the measured soil chemical properties after 3 months 
TABLE 2 | Biomarkers of different plant species as revealed by soil bacteria (OTUs) enriched in root compartment.

\begin{tabular}{lcccc}
\hline OTU code & \multicolumn{2}{c}{ Abundance } & Biomarker & \\
\cline { 2 - 3 } & Bahiagrass & Stylo & & Taxon \\
\hline OTU1 & $4779 \pm 676^{\mathrm{a}}$ & $1373 \pm 216^{\mathrm{b}}$ & Bahiagrass & Pseudarthrobacter \\
OTU38 & $236 \pm 13^{\mathrm{a}}$ & $178 \pm 6^{\mathrm{b}}$ & Bahiagrass & Sphingomonas \\
OTU158 & $225 \pm 12^{\mathrm{a}}$ & $171 \pm 9^{\mathrm{b}}$ & Bahiagrass & Candidatus Solibacter \\
OTU27 & $220 \pm 6^{\mathrm{a}}$ & $148 \pm 1 \mathrm{~b}$ & Bahiagrass & Uncultured Holophagae \\
OTU81 & $192 \pm 10^{\mathrm{a}}$ & $107 \pm 6^{\mathrm{b}}$ & Bahiagrass & Uncultured Acidobacteriaceae \\
OTU10 & $407 \pm 59^{\mathrm{b}}$ & $925 \pm 134^{\mathrm{a}}$ & Stylo & Tumebacillus \\
OTU18 & $323 \pm 23^{\mathrm{b}}$ & $751 \pm 41^{\mathrm{a}}$ & Stylo & Bacillus drentensis \\
OTU3 & $420 \pm 22^{\mathrm{b}}$ & $558 \pm 16^{\mathrm{a}}$ & Stylo & Uncultured Rhodobiaceae \\
OTU12 & $371 \pm 28^{\mathrm{b}}$ & $498 \pm 9^{\mathrm{a}}$ & Stylo & Bradyrhizobium \\
OTU237 & $61 \pm 9^{\mathrm{b}}$ & $224 \pm 33^{\mathrm{a}}$ & Streptomyces
\end{tabular}

For each plant species, only the top 5 OTUs (abundance > 0.1\%) with significant difference in abundance between plant species were listed. Bahiagrass, Paspalum natatum; Stylo, Stylosanthes guianensis.

TABLE 3 | Biomarkers of different distance in the rhizosphere of two plant species as revealed by soil bacteria (OTUs) enriched.

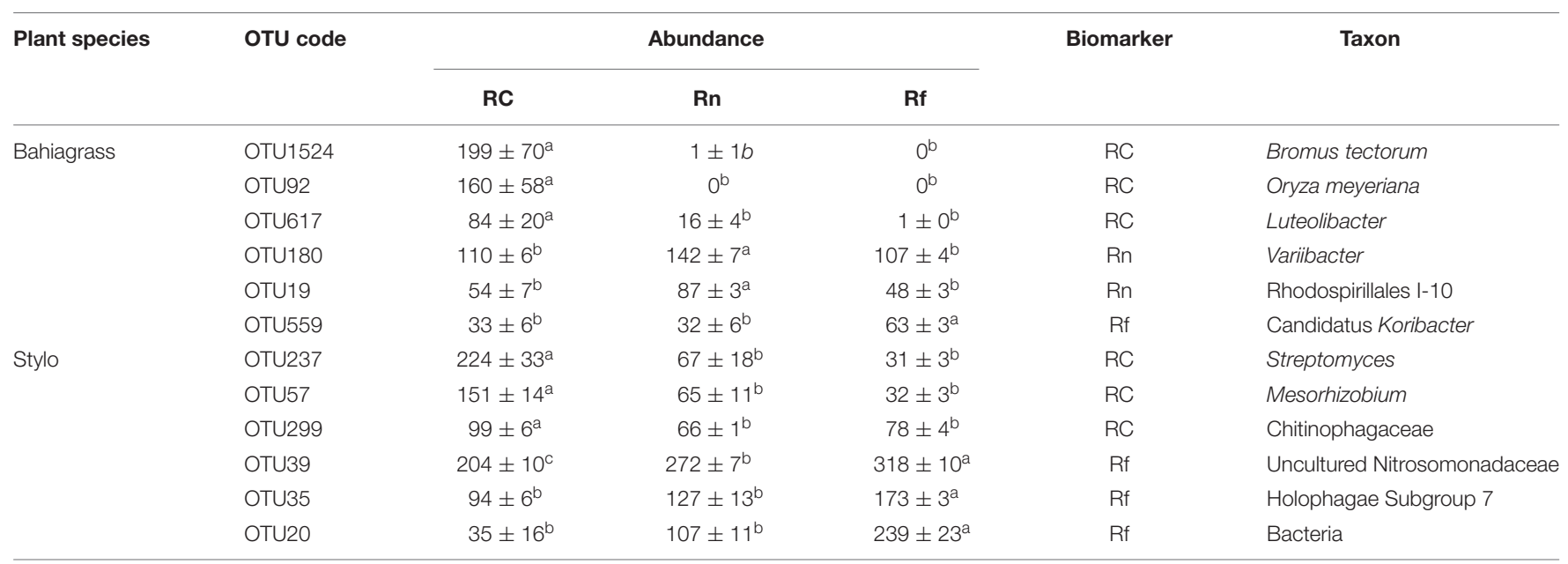

Only the top 3 OTUs (abundance $>0.1 \%$ ) with significant difference in abundance among three distances were listed. No biomarker was observed for near rhizosphere of stylo plants. Bahiagrass, Paspalum natatum; Stylo, Stylosanthes guianensis. RC, root compatment; $R$ n, the near rhizosphere (0-5 mm); $R f$, the far rhizosphere (10-15 mm).

TABLE 4 | Permutational multivariate analysis of variance (PERMANOVA) results of soil bacterial community based on $16 \mathrm{~S}$ rRNA gene sequencing, influences of plant species and distance.

\begin{tabular}{lcccrr}
\hline Source & SS & DF & MS & F & P \\
\hline Plant species & 0.063 & 1 & 0.063 & 4.530 & 3.479 \\
Distance & 0.096 & 2 & 0.048 & 2.218 & $<0.001$ \\
Interaction & 0.061 & 2 & 0.031 & 0.001 \\
Residual & 0.166 & 12 & 0.014 & & $<0.01$ \\
\hline
\end{tabular}

of growth, except that neither plant species nor distance affected available N (Supplementary Table S2). For plant species, $\mathrm{NH}_{4}{ }^{+}$and available $\mathrm{P}$ in bahiagrass soil were significantly higher than those in stylo soil, while total organic $\mathrm{C}$, dissolved organic $\mathrm{C}, \mathrm{NO}_{3}{ }^{-}$, available $\mathrm{K}$ and water content in bahiagrass soil were significantly lower than those in stylo soil. For distance, rhizosphere effect was clear for $\mathrm{NH}_{4}{ }^{+}, \mathrm{NO}_{3}{ }^{-}$and available $\mathrm{K}$ (Figure 1).
It is worth noting that the rhizospere effect on $\mathrm{NH}_{4}{ }^{+}$ and $\mathrm{NO}_{3}{ }^{-}$was stronger for bahiagrass than for stylo (Figure 1), demonstrating the difference in $\mathrm{N}$ requirement between legume and non-legume species. Moreover, available $\mathrm{K}$ exhibited a strong rhizosphere effect, with a sharp decrease from $\mathrm{Rf}$ to RC (Figure 1), indicating the large consumption by plants as well as the high mobility of $\mathrm{K}^{+}$. 


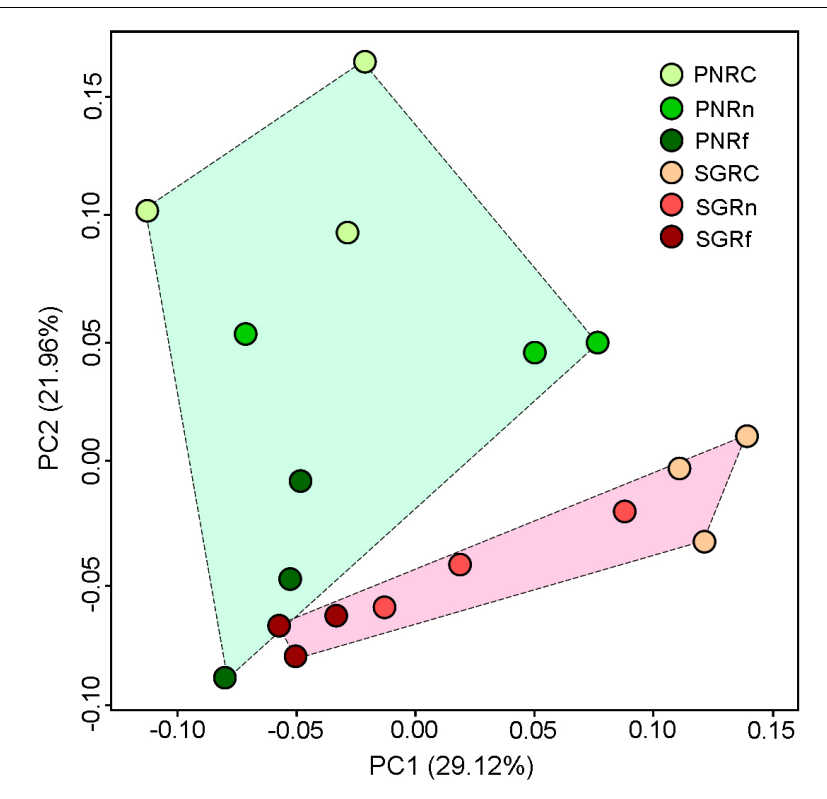

FIGURE 3 | Principal coordinates analysis of soil bacterial community (OUT abundance) as revealed by weighted UniFrac dispersion. PN, bahiagrass (Paspalum natatum); SG, stylo (Stylosanthes guianensis). RC, Rn, and Rf indicate root compartment, the near $(0-5 \mathrm{~mm})$ and the far $(10-15 \mathrm{~mm})$ rhizosphere.

\section{Soil Bacterial Community Structure and Composition as Affected by Plant Species and Distance}

16S rRNA gene sequencing clearly revealed the influences of plant species and distance on the Simpson diversity of bacterial community (Table 1). However, Ace (abundance-based coverage estimator) and Chaol, measures of the predicted species richness in the environments, did not show significant difference between samples. Bacterial diversity in stylo soil was higher than that in bahiagrass soil; moreover, bacterial diversity increased along with the distance apart from roots, exhibiting obvious rhizosphere effect. There was not interaction between plant species and distance for all these parameters (Table $\mathbf{1}$ ).

The main phyla (relative abundance $>5 \%$ ) in rhizosphere were Proteobacteria, Acidobacteria, Actinobacteria, Firmicutes, Chloroflexi, Bacteroidetes, and both plant species and distance from root compartment affected their abundance (Supplementary Figure S2). Bahiagrass enriched significantly higher abundance of Proteobacteria $(P=0.004)$ than stylo, while stylo enriched significantly higher abundance of Actinobacteria $(P=0.031)$ than bahiagrass. Acidobacteria abundance $(P=0.004)$ and Bacteroidetes abundance $(P=0.012)$ significantly rose with increased distance from root compartment, while Actinobacteria abundance $(P=0.006)$ significantly decreased with increased distance (Supplementary Figure S2).

The main bacterial genera (abundance $>1 \%$ ) in soil were shown in Figure 2. The abundance of Pseudarthrobacter was much higher in bahiagrass soil than that in stylo soil, while the abundance of Tumebacillus and Bacillus was much lower in bahiagrass soil. We identified some biomarker bacteria of both plant species and of the soil with different distance from root compartment (Supplementary Dataset). The biomarker bacteria of bahiagrass were Pseudarthrobacter, Sphingomonas, Candidatus Solibacter, and some uncultured taxa, in contrast, the biomarker bacteria of stylo were Tumebacillus, Bacillus drentensis, Bradyrhizobium, Streptomyces, and some uncultured taxa (Table 2). For bahiagrass, the biomarker bacteria of root compartment were Bromus tectorum, Oryza meyeriana, and Luteolibacter; those of near rhizosphere were Variibacter, Rhodospirillales I-10; and those of far rhizosphere were
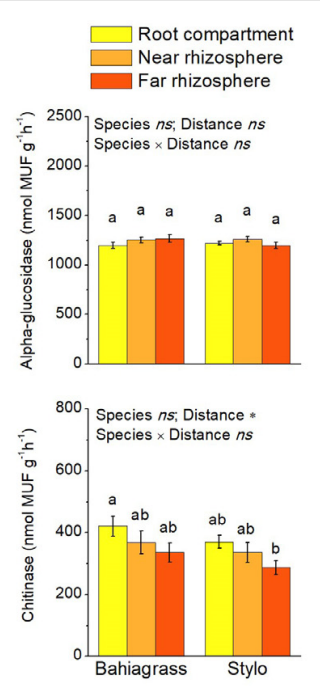
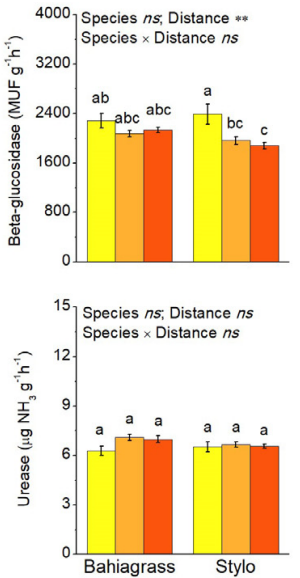
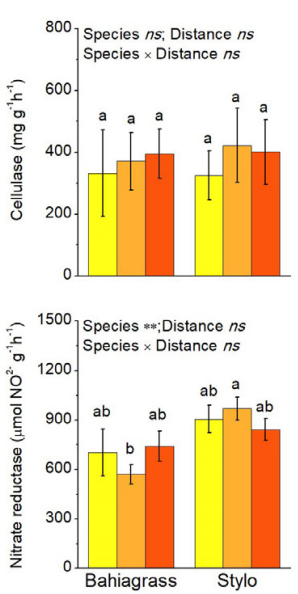
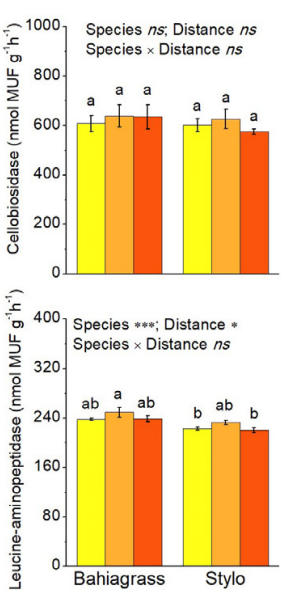

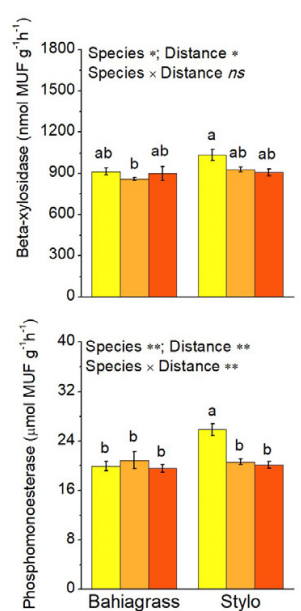

FIGURE 4 | Soil enzyme activities as affected by plant species and distance. Bars with different letters are significantly different (Tukey HSD test, $P<0.05)$. Near rhizosphere and far rhizosphere indicate the rhizosphere space of 0-5 mm and 10-15 mm apart from rhizoplane, respectively. Bahiagrass, Paspalum natatum; Stylo, Stylosanthes guianensis. 

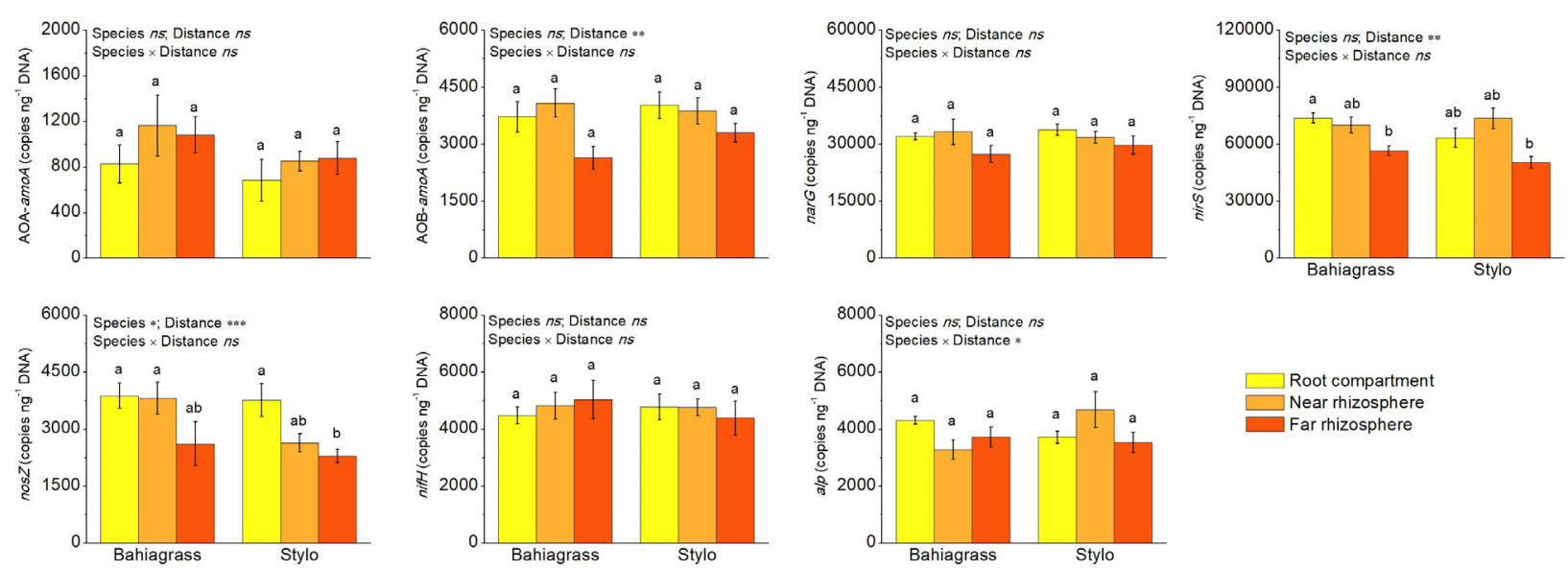

FIGURE 5 | The abundances of bacterial functional genes as affected by plant species and distance. Bars with different letters are significantly different (Tukey HSD test, $P<0.05)$. Near rhizosphere and far rhizosphere indicate the rhizosphere space of $0-5 \mathrm{~mm}$ and $10-15 \mathrm{~mm}$ apart from rhizoplane, respectively. Bahiagrass, Paspalum natatum; Stylo, Stylosanthes guianensis.

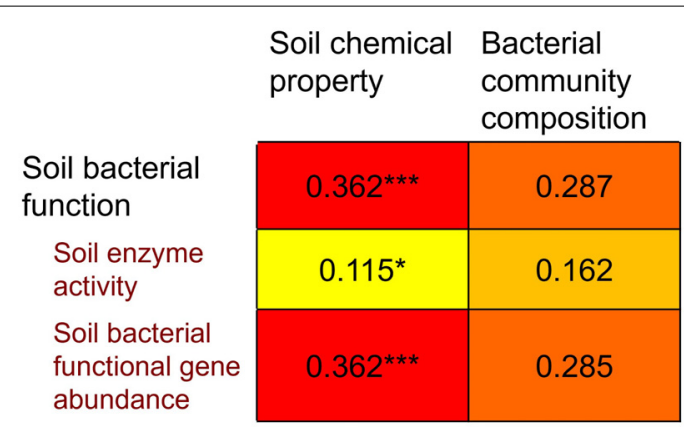

FIGURE 6 | Spearman's rank correlations ( $r$-values), determined via Mantel test, relating to Bray-Cutris distance dissimilarity matrices generated from soil bacterial community composition at genus level, and to Euclidean distance dissimilarity matrices generated from soil chemical property and soil microbial function. Soil microbial function is further divided into two categories: soil enzyme activity and soil bacterial functional gene abundance.

Candidatus Koribacter. For stylo, the biomarker bacteria of root compartment were Streptomyces, Mesorhizobium, and Chitinophagaceae; those of far rhizosphere were uncultured Nitrosomonadaceae, Holophagae Subgroup 7, and some unknown taxa (Table 3). The difference in biomarker bacterial taxa highlights the influences of plant species and distance on soil bacterial community.

Permutational multivariate analysis of variance (PERMANOVA) based on 16S rRNA gene sequencing indicates that both plant species $(P<0.001)$ and distance $(P<0.001)$ significantly affected bacterial community structure with significant interaction between them $(P<0.01)$ (Table 4). PCoA also suggests the distinct bacterial community structures between plant species, and among the different distance (Figure 3). Moreover, the dissimilarity in bacterial community structure between plant species decreased along with the distance apart from roots.

\section{Soil Enzyme Activity as Affected by Plant Species and Distance}

The influences of plant species and distance on soil enzyme activity were shown in Figure 4. Plant species and/or distance significantly affected the activities of soil enzymes except alphaglucosidase, cellulase, cellobiosidase and urease (Figure 4 and Supplementary Table S3). Leucine-aminopeptidase activity was higher but the activities of beta-xylosidase, nitrate reductase and phosphomonoesterase were lower in bahiagrass soil than in stylo soil (Figure 4 and Supplementary Table S3). On the other hand, the activities of beta-glucosidase, betaxylosidase and chitinase decreased along with the distance apart from roots, indicating the rhizosphere effect. However, the rhizosphere effect on phosphomonoesterase was observed only in stylo soil but not in bahiagrass soil (Figure 4 and Supplementary Table S3).

\section{The Abundances of Functional Genes as Affected by Plant Species and Distance}

Apart from soil enzyme activity, bacterial functional gene abundance was also quantified to represent soil bacterial function. RT-qPCR reveals that the functional genes were significantly affected by plant species and/or distance except AOA-amoA, narG, nifH, and alp (Figure 5). Plant species significantly affected only nos $Z$, with nos $Z$ abundance higher in bahiagrass soil than stylo soil (Figure 5 and Supplementary Table S3). On the other hand, distance significantly affected AOBA-amoA, nirS, and nos $Z$, with their abundances decreasing along with the distance apart from roots (Figure 5 and Supplementary Table S3). For alp, there was an interaction between plant species and distance.

\section{Determinant of Soil Bacterial Function}

Mantel test indicates that soil bacterial function was significantly correlated with soil chemical property $(P=0.002)$ but 


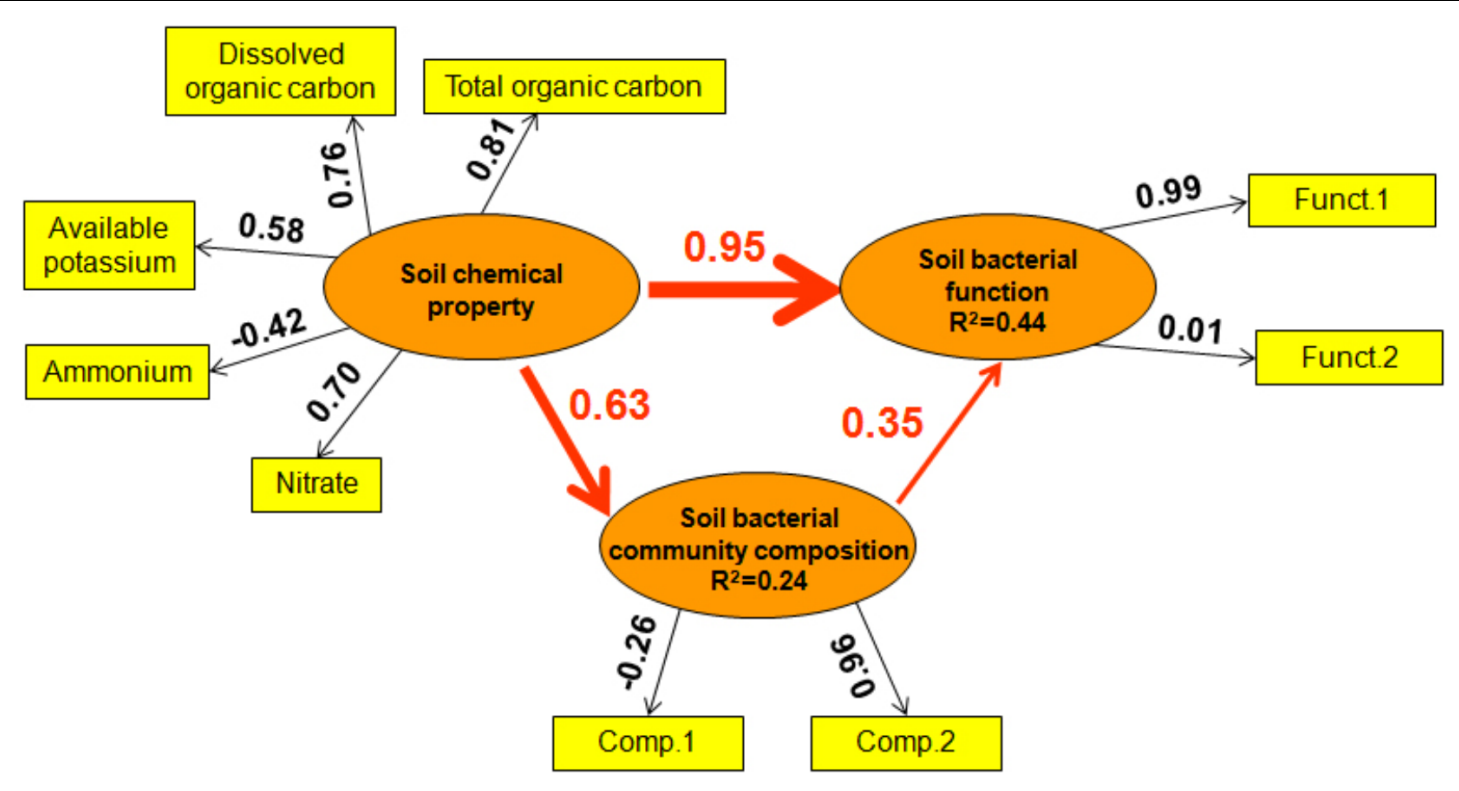

FIGURE 7 | Directed graph of the Partial Least Squares Path Model (PLS-PM). Observed (i.e., measured) variables are represented in a rectangular form, while latent variables (i.e., constructs) are represented in an elliptical form. The loadings (the correlations between a latent variable and its observed variables) are indicated as the values in rectangles, and the path coefficients (between latent variables) and the coefficients of determination ( $R^{2}$ in ellipses) are calculated after 999 bootstraps. The Model was assessed using the Goodness of Fit (GoF) statistic, a measure of the overall prediction performance. The GoF was 0.42.

not with bacterial community composition $(P=0.997)$ (Figure 6), suggesting that bacterial function is affected more strongly by soil chemical property than by bacterial community composition. Furthermore, we divided bacterial function into two categories, e.g., soil enzyme activity and bacterial functional gene abundance. Soil enzyme activity $(P=0.048)$ and bacterial functional gene abundance $(P=0.017)$ were significantly correlated with soil chemical property, respectively, while they were not significantly correlated with bacterial community composition $(P=0.100$ and 0.996, respectively) (Figure 6).

Furthermore, PLS-PM was conducted to illustrate the direct and indirect relationships of soil bacterial function and soil chemical property, bacterial community composition. In general, soil chemical property produced a larger direct effect on soil bacterial function than bacterial community composition (effect size 0.95 vs. 0.35, Figure 7). Additionally, soil chemical property produced an indirect effect on soil bacterial function via its influence on bacterial community composition (effect size 0.63 , Figure 7 ).

\section{DISCUSSION}

In this study, we measured bacterial functional gene abundance and soil enzyme activities (products of functional genes) to indicate bacterial functions. The primers used in this study for bacterial functional genes were bacteria-specific, therefore the functional gene abundance could be well indicative of bacterial functions. However, in contrast, soil enzymes could not be exclusively indicative of bacterial functions because soil enzymes can be originated not only from bacteria but also from other organisms, such as fungi and plants. In this context, it is not surprising that the bacterial community composition was more closely related (higher correlation coefficient) with functional gene abundance than with soil enzyme activity. Although functional genes are inherent to bacterial taxa, their transcription and translation are greatly regulated by environmental conditions (Schreiber et al., 2007; Kim et al., 2016; Hockenberry et al., 2017). Taking nitrate respiration as example, a serial of functional genes (nar, nir) are regulated by anaerobic condition and nitrate presence via transcription network in Pseudomonas aeruginosa (Schreiber et al., 2007). The Shine-Dalgarno (SD) sequence motif is the dominant mechanism of translation initiation in bacteria, and Hockenberry et al. (2017) illustrated that environmental factor (temperature) influenced the translation via $\mathrm{SD}$ sequence mechanism by comparing mesophiles and thermophiles. Therefore, it is reasonable to find that functional gene abundance was significantly correlated with soil chemical property in this study. Additionally, soil chemical property can exert direct influences on soil enzyme activity. A metaanalysis pooling data from 40 ecosystems indicated that $\mathrm{pH}$ affected $\beta$-1,4-glucosidase, cellobiohydrolase, $\beta-1,4-\mathrm{N}$ acetylglucosaminidase, phosphatase, leucine aminopeptidase, phenol oxidase and peroxidase activities, and soil organic matter affected the former four enzyme activities (Sinsabaugh et al., 2008). As aforementioned, however, it is likely that soil chemical property correlate with functional gene abundance more closely than with soil enzyme activity, as revealed in this study. 
Our results did not support a significant correlation between community composition and function. The factor weakening the correlation between community composition and functions can be the bacterial multifunctionality and functional redundancy. There are some versatile bacterial taxa with multiple functions in diverse ecosystems (Hartmann et al., 2015), e.g., some isolates from Bacillus and Pseudomonas (Jeong et al., 2010; Chaturvedi et al., 2014). Ryan et al. (2009) suggested that the functioning of versatile isolates depends on environmental conditions. This highlights the critical role of soil chemical property in shaping bacterial community function as revealed in this study. Functional redundancy is normally at high level in microbes (Nannipieri et al., 2017). Banerjee et al. (2016) showed the microbial functional redundancy in an organic matter decomposition experiment, where the abundance of dominant decomposer changed 4300 -fold with the decomposition rate maintaining similar. In this context, interpreting bacterial function with taxonomic information can be difficult, although $16 \mathrm{~S}$ rRNA marker gene can be sequenced to predict microbial functions using a computational approach (PICRUSt) (Langille et al., 2013) or other tools. In general, for the bacterial community functions, soil chemical properties and bacterial community composition can be regarded as external and internal affecting factors, respectively. In this study, it seems that external factors are more influential than internal factor to shape the bacterial function profile.

Plants can alter both bacterial community composition and function via the modification of soil chemical property by roots. For example, Wang et al. (2015) suggested the importance of soil physiochemical properties in determining the activities of ammonia oxidizers and nitrite oxidizers. In this study, we found that the soil chemical property was much different between bahiagrass and stylo, which might be resulted from the difference in root uptake and root exudation and could contribute greatly to the difference in bacterial community composition and function.

It is well known that rhizosphere effect depends on the distance from rhizoplane (Wang et al., 2014; Razavi et al., 2016). In this study, we set up the near and far rhizosphere using compartmentation with nylon mesh to characterize the rhizosphere effect. We found that soil bacterial function showed strong rhizosphere effect, in terms of $\mathrm{C}$ cycling (activities of beta-glucosidase and beta-xylosidase), $\mathrm{N}$ cycling (chitinase activity, abundances of narG, nirS and nos Z), and $\mathrm{P}$ cycling (phosphomonoesterase activity, alp abundance). It seems that the rhizosphere effect on $\mathrm{N}$ cycling is more extensive, probably due to the complexity of $\mathrm{N}$ cycling in soil. The differential influences of stylo and bahiagrass on soil chemical properties were demonstrated in this study and previously (Zhou et al., 2017), which might further lead to different bacterial community composition (or specific populations) and functions, as indicated in this study. The specifically recruited microbial assembly and the associated functions can support better plant growth performance, especially under environmental stresses (Bai et al., 2015), depending on plant species.

\section{CONCLUSION}

In conclusion, with stylo (legume) and bahiagras (grass) for comparison, we found that they differentially affected soil chemical property. The contents of organic $\mathrm{C}, \mathrm{NO}_{3}^{-}$and available $\mathrm{K}$ were higher while those of $\mathrm{NH}_{4}{ }^{+}$and available $\mathrm{P}$ were lower in stylo soil. The biomarker bacteria of stylo and bahiagrass were Tumebacillus, Bacillus drentensis, Bradyrhizobium, Streptomyces, and Pseudarthrobacter, Sphingomonas, Candidatus Solibacter, respectively. Soil bacterial function was characterized by soil enzyme activity and bacterial functional gene abundance. The activities of beta-xylosidase, nitrate reductase and phosphomonoesterase in stylo soil were higher than those in bahiagrass soil, while leucine-aminopeptidase activity and nos $Z$ abundance in stylo soil were lower than those in bahiagrass soil. Spearman's correlation determined by Mantel test suggests a significant relationship between soil chemical property and bacterial function. Path analysis indicated a stronger direct and indirect effect of soil chemical property on bacterial function than that of bacterial community composition. Additionally, rhizosphere effect was observed for some parameters of soil chemical property, bacterial community composition, and bacterial function, especially those involved in $\mathrm{N}$ cycling. In conclusion, these data suggest that bacterial function is affected more strongly by soil chemical property than by bacterial community composition, and legume and grass can affect soil bacterial function in different patterns.

\section{AUTHOR CONTRIBUTIONS}

QY, HZ, and YZ designed this study. YZ and YQ performed the experiments. ZF and XL contributed to the molecular analysis. YZ and QY analyzed the data. YZ, QY, and HZ wrote the manuscript with help from other co-authors.

\section{FUNDING}

This work was supported by Natural Science Foundation of China (31570395), Guangdong Academy of Science (2017GDASCX-0402 and 2019GDASYL-0103012), and Guangdong Science and Technology Program (2018B090918090 and 2016A020210071).

\section{SUPPLEMENTARY MATERIAL}

The Supplementary Material for this article can be found online at: https://www.frontiersin.org/articles/10.3389/fmicb. 2019.00798/full\#supplementary-material 


\section{REFERENCES}

Adesemoye, A. O., Torbert, H. A., and Kloepper, J. W. (2008). Enhanced plant nutrient use efficiency with PGPR and AMF in an integrated nutrient management system. Can. J. Microbiol. 54, 876-886. doi: 10.1139/w08-081

Bai, Y., Müller, D. B., Srinivas, G., Garrido-Oter, R., Potthoff, E., Rott, M., et al. (2015). Functional overlap of the Arabidopsis leaf and root microbiota. Nature 528, 364-369. doi: 10.1038/nature 16192

Banerjee, S., Kirkby, C. A., Schmutter, D., Bissett, A., Kirkegaard, J. A., and Richardson, A. E. (2016). Network analysis reveals functional redundancy and keystone taxa amongst bacterial and fungal communities during organic matter decomposition in an arable soil. Soil Biol. Biochem. 97, 188-198. doi: 10.1016/j. soilbio.2016.03.017

Barberán, A., Ramirez, K. S., Leff, J. W., Bradford, M. A., Wall, D. H., and Fierer, N. (2014). Why are some microbes more ubiquitous than others? Predicting the habitat breadth of soil bacteria. Ecol. Lett. 17, 794-802. doi: 10.1111/ele.12282

Burns, R. G., DeForest, J. L., Marxsen, J., Sinsabaugh, R. L., Stromberger, M. E., Wallenstein, M. D., et al. (2013). Soil enzymes in a changing environment: current knowledge and future directions. Soil Biol. Biochem. 58, 216-234. doi: 10.1016/j.soilbio.2012.11.009

Caporaso, J. G., Lauber, C. L., Walters, W. A., Berg-Lyons, D., Huntley, J., Fierer, N., et al. (2012). Ultra-high-throughput microbial communityanalysis on the Illumina HiSeq and MiSeq platforms. ISME J. 6, 1621-1624. doi: 10.1038/ ismej. 2012.8

Carter, M. R., and Gregorich, E. G. (2008). Soil Sampling and Methods of Analysis (Second Edition). Boca Raton, FL: CRC Press.

Chaturvedi, V., Bhange, K., Bhatt, R., and Verma, P. (2014). Production of kertinases using chicken feathers as substrate by a novel multifunctional strain of Pseudomonas stutzeri and its dehairing application. Biocatal. Agric. Biotech. 3, 167-174. doi: 10.1016/j.bcab.2013.08.005

Chen, D., Zhou, L., Wu, J., Hsu, J., Lin, Y., and Fu, S. (2012). Tree girdling affects the soil microbial community by modifying resource availability in two subtropical plantations. Appl. Soil Ecol. 53, 108-115. doi: 10.1016/j.apsoil.2011.10.014

Cui, H., Zhou, Y., Gu, Z., Zhu, H., Fu, S., and Yao, Q. (2015). The combined effects of cover crops and symbiotic microbes on phosphatase gene and organic phosphorus hydrolysis in subtropical orchard soils. Soil Biol. Biochem. 82, 119-126. doi: 10.1016/j.soilbio.2015.01.003

Fernandez, A. L., Sheaffer, C. C., Wyse, D. L., Staley, C., Gould, T. J., and Sadowsky, M. J. (2016). Associations between soil bacterial community structure and nutrient cycling functions in long-term organic farm soils following cover crop and organic fertilizer amendment. Sci. Total Environ. 566, 949-959. doi: 10.1016/j.scitotenv.2016.05.073

Fisher, K. A., Yarwood, S. A., and James, B. R. (2017). Soil urease activity and bacterial ureC gene copy numbers: effect of pH. Geoderma 285, 1-8. doi: 10. 1016/j.geoderma.2016.09.012

Fu, S. F., He, S., Shi, X. S., Katukuri, N. R., Dai, M., and Guo, R. B. (2015). The chemical properties and microbial community characterization of the thermophilic microaerobic pretreatment process. Bioresour. Tech. 198, 497-502. doi: 10.1016/j.biortech.2015. 09.029

Galand, P. E., Pereira, O., Hochart, C., Auguet, J. C., and Debroas, D. (2018). A strong link between marine microbial community composition and function challenges the idea of functional redundancy. ISME J. 12, 2470-2478. doi: 10.1038/s41396-018-0158-1

Ghosh, P. K., Tripathi, A. K., Bandyopadhyay, K. K., and Manna, M. C. (2009). Assessment of nutrient competition and nutrient requirement in soybean/sorghum intercropping system. Eur. J. Agron. 31, 43-50. doi: 10.1016/ j.eja.2009.03.002

Gransee, A., and Wittenmayer, L. (2000). Qualitative and quantitative analysis of water-soluble root exudates in relation to plant species and development. J. Plant Nutr. Soil Sci. 163, 381-385. doi: 10.1002/1522-2624(200008)163: 4<381::AID-JPLN381>3.0.CO;2-7

Grigulis, K., Lavorel, S., Krainer, U., Legay, N., Baxendale, C., Dumont, M., et al. (2013). Relative contributions of plant traits and soil microbial properties to mountain grassland ecosystem services. J. Ecol. 101, 47-57. doi: 10.1111/13652745.12014

Guo, M., Gong, Z., Miao, R., Su, D., Li, X., Jia, C., et al. (2017). The influence of root exudates of maize and soybean on polycyclic aromatic hydrocarbons degradation and soil bacterial community structure. Ecol. Eng. 99, 22-30. doi: 10.1016/j.ecoleng.2016. 11.018

Guyonnet, J. P., Vautrin, F., Meiffren, G., Labois, C., Cantarel, A. A. M., Michalet, S., et al. (2017). The effects of plant nutritional strategy on soil microbial denitrification activity through rhizosphere primary metabolites. FEMS Microbiol. Ecol. 93, 1-11. doi: 10.1093/femsec/fix022

Haichar, F. Z., Marol, C., Berge, O., Rangel-Castro, J. I., Prosser, J. I., Balesdent, J., et al. (2008). Plant host habitat and root exudates shape soil bacterial community structure. ISME J. 2, 1221-1230. doi: 10.1038/ismej.2008.80

Hammer, Ø, Harper, D. A. T., and Ryan, P. D. (2001). PAST-palaeontological statistics software package for education and data analysis. Palaeontol. Electron 4:9.

Hartmann, M., Frey, B., Mayer, J., Mäder, P., and Widmer, F. (2015). Distinct soil microbial diversity under long-term organic and conventional farming. ISME J. 9, 1177-1194. doi: 10.1038/ismej.2014.210

Hockenberry, A. J., Stern, A. J., Amaral, L. A. N., and Jewett, M. C. (2017). Diversity of translation initiation mechanisms across bacterial species is driven by environmental conditions and growth demands. Mol. Biol. Evol. 35, 582-592. doi: 10.1093/molbev/msx310

Hu, Y., Xia, Y., Sun, Q., Liu, K., Chen, X., Ge, T., et al. (2018). Effects of long-term fertilization on phoD-harboring bacterial community in Karst soils. Sci. Total Environ. 628, 53-63. doi: 10.1016/j.scitotenv.2018.01.314

Hünninghaus, M., Koller, R., Kramer, S., Marhan, S., Kandeler, E., and Bonkowski, M. (2017). Changes in bacterial community composition and soil respiration indicate rapid successions of protist grazers during mineralization of maize crop residues. Pedobiologia 62, 1-8. doi: 10.1016/j.pedobi.2017.03.002

ISO/TS 22939 (2010). Soil Quality-measurement of Soil Enzyme Activity Patterns in Soil Samples Using Fluorogenic Substrates in Micro-well Plates. Geneva: International Organization for Standardization.

Isobe, K., and Tsuboki, Y. (1998). Relationship between the amount of root exudate and the infection rate of arbuscular mycorrhizal fungi in gramineous and leguminous crops. Plant Prod. Sci. 1, 37-38. doi: 10.1626/pps.1.37

Jensen, E. S. (1996). Grain yield, symbiotic N2 fixation and interspecific competition for inorganic $\mathrm{N}$ in pea-barley intercrops. Plant Soil 182, 25-38. doi: 10.1007/BF00010992

Jeong, J. H., Jeon, Y. D., Lee, O. M., Kim, J. D., Lee, N. R., Park, G. T., et al. (2010). Characterization of a multifunctional feather-degrading Bacillus subtilis isolated from forest soil. Biodegradation 21, 1029-1040. doi: 10.1007/s10532010-9363-y

Kandeler, E., Marschner, P., Tscherko, D., Gahoonia, T. S., and Nielsen, N. E. (2002). Microbial community composition and functional diversity in the rhizosphere of maize. Plant Soil 238, 301-312. doi: 10.1023/A:1014479 220689

Kim, S. K., Jung, K. H., and Chai, Y. G. (2016). Changes in Bacillus anthracis CodY regulation under host-specific environmental factor deprived conditions. BMC Genomics 17:645. doi: 10.1186/s12864-0163004-8

Kirk, J. L., Klironomos, J. N., Lee, H., and Trevors, J. T. (2005). The effects of perennial ryegrass and alfalfa on microbial abundance and diversity in petroleum contaminated soil. Environ. Pollut. 133, 455-465. doi: 10.1016/j. envpol.2004.06.002

Knee, E. M., Gong, F. C., Gao, M., Teplitski, M., Jones, A. R., Foxworthy, A., et al. (2001). Root mucilage from pea and its utilization by rhizosphere bacteria as a sole carbon source. Mol. Plant Microbe Interact. 14, 775-784. doi: 10.1094/ MPMI.2001.14.6.775

Kolton, M., Graber, E. R., Tsehansky, L., Elad, Y., and Cytryn, E. (2017). Biocharstimulated plant performance is strongly linked to microbial diversity and metabolic potential in the rhizosphere. New Phytol. 213, 1393-1404. doi: 10. 1111/nph.14253

Kourtev, P. S., Ehrenfeld, J. G., and Häggblom, M. (2003). Experimental analysis of the effect of exotic and native plant species on the structure and function of soil microbial communities. Soil Biol. Biochem. 35, 895-905. doi: 10.1016/S00380717(03)00120-2

Langille, M. G., Zaneveld, J., Caporaso, J. G., McDonald, D., Knights, D., Reyes, J. A., et al. (2013). Predictive functional profiling of microbial communities using 16S rRNA marker gene sequences. Nat. Biotechnol. 31, 814-821. doi: $10.1038 /$ nbt. 2676 
Lowe, R. H., and Evans, H. J. (1964). Preparation and some properties of a soluble nitrate reductase from Rhizobium japonicum. Biochim. Biophys. Acta 85, 377-389. doi: 10.1016/0926-6569(64)90301-3

Marilley, L., Vogt, G., Blanc, M., and Aragno, M. (1998). Bacterial diversity in the bulk soil and rhizosphere fractions of Lolium perenne and Trifolium repens as revealed by PCR restriction analysis of 16 S rDNA. Plant Soil 198, 219-224. doi: 10.1023/A:1004309008799

Miller, G. L., Blum, R., Glennon, W. E., and Burton, A. L. (1960). Measurement of carboxymethylcellulase activity. Anal. Biochem. 1, 127-132. doi: 10.1016/00032697(60)90004-X

Nannipieri, P., Ascher, J., Ceccherini, M. T., Landi, L., Pietramellara, G., and Renella, G. (2017). Microbial diversity and soil functions. Eur. J. Soil Sci. 68, 12-26. doi: 10.1111/ejss.4_12398

Ofek-Lalzar, M., Sela, N., Goldman-Voronov, M., Green, S. J., Hadar, Y., and Minz, D. (2014). Niche and host-associated functional signatures of the root surface microbiome. Nat. Commun. 5:4950. doi: 10.1038/ncomms5950

Paterson, E. (2003). Importance of rhizodeposition in the coupling of plant and microbial productivity. Eur. J. Soil Sci. 54, 741-750. doi: 10.1046/j.1351-0754. 2003.0557.x

Pivato, B., Bru, D., Busset, H., Deau, F., Matejicek, A., Philippot, L., et al. (2017). Positive effects of plant association on rhizosphere microbial communities depend on plant species involved and soil nitrogen level. Soil Biol. Biochem. 114, 1-4. doi: 10.1016/j.soilbio.2017.06.018

R Development Core Team (2012). R: a language and environment for statistical computing. $R$ Found. Stat. Comput. 1:409. Available at: http://www.rproject.org

Razavi, B. S., Zarebanadkouki, M., Blagodatskaya, E., and Kuzyakov, Y. (2016). Rhizosphere shape of lentil and maize: spatial distribution of enzyme activities. Soil Biol. Biochem. 96, 229-237. doi: 10.1016/j.soilbio.2016.02.020

Rognes, T., Flouri, T., Nichols, B., Quince, C., and Mahé, F. (2016). VSEARCH: a versatile open source tool for metagenomics. PeerJ 4:e2584. doi: 10.7717/peerj. 2584

Rovira, A. D. (1969). Plant root exudates. Bot. Rev. 35, 35-57. doi: 10.1007/ BF02859887

Ryan, R. P., Monchy, S., Cardinale, M., Taghavi, S., Crossman, L., Avison, M. B., et al. (2009). The versatility and adaptation of bacteria from the genus Stenotrophomonas. Nat. Rev. Microbiol. 7, 514-525. doi: 10.1038/nrmicro 2163
Schreiber, K., Krieger, R., Benkert, B., Eschbach, M., Arai, H., Schobert, M., et al. (2007). The anaerobic regulatory network required for Pseudomonas aeruginosa nitrate respiration. J. Bacteriol. 189, 4310-4314. doi: 10.1128/JB. 00240-07

Sinsabaugh, R. L., Lauber, C. L., Weintraub, M. N., Ahmed, B., Allison, S. D., Crenshaw, C., et al. (2008). Stoichiometry of soil enzyme activity at global scale. Ecol. Lett. 11, 1252-1264. doi: 10.1111/j.1461-0248.2008.01245.x

Tabatabai, M. A., and Bremner, J. M. (1972). Assay of urease activity in soils. Soil Biol. Biochem. 4, 479-487. doi: 10.1016/0038-0717(72)90064-8

Thion, C. E., Poirel, J. D., Cornulier, T., De Vries, F. T., Bardgett, R. D., and Prosser, J. I. (2016). Plant nitrogen-use strategy as a driver of rhizosphere archaeal and bacterial ammonia oxidiser abundance. FEMS Microbiol. Ecol. 92, 1-11. doi: 10.1093/femsec/fiw091

Wang, B., Zhao, J., Guo, Z., Ma, J., Xu, H., and Jia, Z. (2015). Differential contributions of ammonia oxidizers and nitrite oxidizers to nitrification in four paddy soils. ISME J. 9, 1062-1075. doi: 10.1038/ismej.2014.194

Wang, Y., Luo, C., Li, J., Yin, H., and Zhang, G. (2014). Influence of plants on the distribution and composition of PBDEs in soils of an e-waste dismantling area: evidence of the effect of the rhizosphere and selective bioaccumulation. Environ. Pollut. 186, 104-109. doi: 10.1016/j.envpol.2013.11.018

Wei, C., Yu, Q., Bai, E., Lü, X., Li, Q., Xia, J., et al. (2013). Nitrogen deposition weakens plant-microbe interactions in grassland ecosystems. Glob. Change Biol. 19, 3688-3697. doi: 10.1111/gcb.12348

Zhou, Y., Zhu, H., Fu, S., and Yao, Q. (2017). Metagenomic evidence of stronger effect of stylo (legume) than bahiagrass (grass) on taxonomic and functional profiles of the soil microbial community. Sci. Rep. 7:10195. doi: 10.1038/s41598017-10613-6

Conflict of Interest Statement: The authors declare that the research was conducted in the absence of any commercial or financial relationships that could be construed as a potential conflict of interest.

Copyright (c) 2019 Zhou, Qin, Liu, Feng, Zhu and Yao. This is an open-access article distributed under the terms of the Creative Commons Attribution License (CC BY). The use, distribution or reproduction in other forums is permitted, provided the original author(s) and the copyright owner(s) are credited and that the original publication in this journal is cited, in accordance with accepted academic practice. No use, distribution or reproduction is permitted which does not comply with these terms. 